\title{
Social Community Behavior Toward Residents With Mental Retardation At "Idiot Village" Sidoharjo Jambon Ponorogo
}

\author{
Muhammad Hanif ${ }^{1}$ \\ Lecturer at Magister Program of Social Sciences,PGRI University of Madiun \\ Corresponding Author: Muhammad Hanif ${ }^{\text {Th }}$
}

\begin{abstract}
This study proposed to analyze and describe the social community behavior towards the sufferers of mental retardation at "idiot village" Sidoharjo Village, Jambon Sub-district, Ponorogo Regency. This research has been conducted since 2014-2017 by qualitative approach. Research subject by purposive sampling technique. While the data retrieval technique throughout observation, interview, and chalking up document. The data analysis uses the modeling of Strauss and Corbin. The result of spatial research on the social community behavior towards sufferers of mental retardation. Such social behavior is predisposed by positive attitudes toward the citizens of mental retardation has been formed into various strengthening actions for the sufferers. As the result, the sufferers of mental retardation could normally havingbacktheirwell of behavioral, family, and social activities, although still limited. Actors in various social behaviors are community leaders, religious leaders, and youth leaders. The factors behind it are: (a) the belief of the child is the deposit of God, (b) the notion of mental retardation, (c) the cultivation of mutual gathering work, (d) empathy and the strong will to stay together, (e) income which is increasing and emotional satisfaction when it can help the residents of mental retardation.
\end{abstract}

Keywords -Social Behavior, Idiot Village, Mental Retardation, Sidoharjo Vellage, Persons with Disabilities

\section{BACKGROUND}

Ponorogo regency was famously known for its unique Reyog-arts world class. Amidst its rich culture and social capital of such national and international reputations, Ponorogo has another phenomenal and unique side of the existence of villages whose citizens are subjected to mental retardation so the villages are named with "idiot villages". The villagesare located in the village of Krebet, Sidoharjo, KarangPatihan and Pandak. From the village exec, the most retarded resident'svillage is the Sidoharjo, Jambon sub-district. The sufferers of mental retardation number areup to 138 people or reach $2.20 \%$ of the total villagers. However, the name "idiot village" to the villages above because not everyone who suffers mental retardation is an idiot, and not all disabled citizens are mental retardation. Previous studies have found citizens suffering from other disabilities, disability, mental illness, and others (Hanif, 2016). They are categorized as Persons with Disabilities (ODK) with conditions as set forth in the table below

Table 1. Data of Individuals with Mental Disabilities and Mental Retardation of Sidoharjo Village.

\begin{tabular}{|c|c|c|c|c|c|c|}
\hline \multicolumn{6}{|c|}{ Persons With Disabilities } & \multirow[t]{2}{*}{ Amount } \\
\hline $\begin{array}{c}\text { Mental } \\
\text { Retardation }\end{array}$ & $\begin{array}{l}\text { Physical } \\
\text { Disorder }\end{array}$ & $\begin{array}{l}\text { Deaf } \\
\text { Mute }\end{array}$ & $\begin{array}{l}\text { Speech } \\
\text { Impaired }\end{array}$ & $\begin{array}{l}\text { Pyshical- } \\
\text { Paralyzed }\end{array}$ & $\begin{array}{l}\text { Crazy/ } \\
\text { Stress }\end{array}$ & \\
\hline 138 & 5 & 9 & 3 & 4 & 5 & 164 \\
\hline
\end{tabular}

(Source: Result of author joint researchwith FSB, February 2015)

The residents with mental retardation in the village have many limitations but they can live their own life in a long time. Itcan not be separated from interpersonal relationships with other citizens around them. Therefore, many questions arise, especially for Sidoharjo Village which has the largest population compared to other idiot villages. The question is about how the social community behavior toward the sufferers of mental retardation, how the actions, what factors are behind it, who the actors, and how the consequences for the citizens of mental retardation? The purpose of this study is to analyze and describe the social behavior of people towards the retardation of idiot village idiot village Sidoharjo Village 


\section{A. Social Community Behavior}

\section{LITERATURE REVIEW}

Social behavior is a community behavior that takes place in dealing with environmental factors resulting in consequences or changes in behavior (Skinner, 2013: 459). The basic concept of social behavior is "reinforcement", while the repetition of the behavior can not be formulated apart from its effect on the behavior itself. The focus is on causal relationships with behavior within an environment where social behavior is a response or reaction to external push. Behavior occurs through the process of stimulus to the organism, and then the organism responds (SOR theory).

Hurlock (1998: 250)examinesthat Social behavior is also interpreted as the behavior of a social community in accordance with social demands or the ability to become a social person.Dealing with Hurlock, Skinner (Sarwono\&Meinarno, 2011: 17)argues that human behavior developed and defended by community members who reinforce individuals to behave as society wants. Whereas according to Lindgren(Sudrajat, 2008: 75), social behavior is manifested through attitudes that can lead to relatively fixed interpersonal action. Furthermore, Thursione (Ahmadi, 2007: 150) argues that social behavior are the attitudes of social community regardingwith the social objects and are repeatedly stated. The subject of social attitudes is the people within the group. The attitude according to Travers and Gagne (Ahmadi, 2007: 151) involves either cognitive, affective, or conative aspects. This attitude serves as a guide to achieve the desired goals and avoids unwanted results, maintain and increase self-esteem, tools to express the values and self-concept, and so forth (Rahman, 2013: 129-130). Thus a review concerningwith the attitude crucially neededto be done because the attitude is closely related to the behavior and illustrates the tendency to act. This attitude is seen as a predictor of the social behavior of citizens towards the citizens with mental retardation.

Baron \& Byrne (2002: 9-13) have extendedthe factors that influence social behavior, namely; behavioral factors and characteristics of others, knowledge, environment, and cultural background. Factors that influence social behavior within social psychology dimension are classified into internal and external factors. Internal factors are human habits collected within him that are used to react and adjust toeach stuff. While external factors relating to social attitudes that include education, religion, culture, environment, and socioeconomics (Walgito, 2004: 48-51). Onthe other sides, based on the theory of social exchange, human action draws from the scheme of giving to getting back in equal amounts. There are three elements of reward, sacrifice, and profit. Although human beings are constantly seeking material gain, there are those who have engaged in social exchanges and produce non-material things or emotional satisfaction (Homans in Ritzer, 2012: 195-198, and Wirawan, 2012: 174-176). In addition, human actions are also linkedto discomfort feelings. This is as presented by cognitive dissonance theory; (a) Man has a desire for consistency in his beliefs, attitudes, and attitudes of stability and consistency, (b) Dissonance is created by inconsistencies to lead to consistency, (c) Dissonance is a feeling of dislike that encourages people to take action- action to obtain consonance and / or reduce dissonance (Festinger in Azwar, 2011: 46-47, Myers, 2012: 164).

As matter of fact, Social behavior can not be separated from culture because human have close relationstoit in which in cultural theory it is said that culture influences man in carrying out his life through arelationship with his environment. So that social action of society is closely related to the values that poured into the norms. In the social behavior of the community, there is often a tendency with patterns of action and way of thinking as a result of aculture that is usually called behavioral attitude (Malinowski in Soekanto, 2006: 149-150, Rickert in Keesing, 1997). Thus it can be underlined the influence factors against social behavior are the attitude, religion, education, culture, environment, and socio-economics of the people.

\section{B. Residents with Mental retardation}

Residents with mental retardation are people at sidoharjovillage in which sufferer feeble-minded, mentally retarded, oligophrenic, mental disorder, or mental deficits. Maramis(2005: 386) sees mental retardation as a person who has an abnormality or weakness with a lack of intelligence. Whereas, according to American Association on Mental Deficiency (AAMD)mental retardationclassified into; IQ: 0-25 categorized Idiot, IQ: 2550 categorized Imbecil, and IQ: 50-70 categories of Debilor moron. The debile category is light and educable mental retardation (can be educated). The small category is medium and trainable mental retardation (can be trained). The Idiot category is a severe mental retardation and the mentally depressed sufferer, requiring complete lifelong care, for not being able to live without the help of others (Nevid, Rathus\& Greene, 2003: 149150). The IQ test is not the only benchmark that can be used to determine the severity of mental retardation but also needs to be assessed based on a large number of different specific skills. Mental retardation may be caused by such: genetic influences such as multiple gene disorders and chromosomal aberrations, deprivation, abuse, drugs while still in the womb, difficulties in labor and delivery, and others (Durand and Barlow, 2007: 305 306). So mental retardation is the result of a pathological process in the brain that causes limitations to intellectual and adaptive functions, or a weakness that occurs in intellectual function and adaptive function. The American Association on Intellectual and Developmental Disabilities (AAID) in 2007, categorized maladaptive 
mental retardation capabilities including the ability to conduct behavioral, family and social activities (Yuliastuti, 2011), and http: // intellectualdisability book / accessed 13 March 2013).

\section{RESEARCH DESIGN}

This is a qualitative research by grounded theory. This study has been conducted during the 2014-2016 in Sidoharjo Village, Jambon Sub-district, Ponorogo Regency. The subjects of this study are community residents including mental retardation residents in various complexities related to behavior and social interaction. Determination of informants with purposive sampling and the subject of his social situation in the form of social behavior of the normal citizens against the mental retardation residents. The data used in this study comes from primary and secondary sources.

The main instrument is the researcher himself using logic and analytic thinking so as to be able to verify the phenomena studied. While auxiliary instruments are used to carry out verification, validation of the phenomena studied. The technique of data collection by observation, interview, and document recording. While data analysis using Qualitative Data Analysis Technique Model Strauss and Corbin.

\section{A. Result}

\section{RESULT AND DISCUSSION}

Residents with mental retardation at the village of SidoharjoJambon based on their mental retardation and ability to live their life activities can be classified into Debil, ImbecileandIdiot with the details as listed in the table below.

Table 2.

Mental Retardation Persons Data Based on Mental Retardation Category

\begin{tabular}{lcccc}
\hline \multicolumn{1}{c}{$\begin{array}{c}\text { Mental retardation } \\
\text { catagories }\end{array}$} & \multicolumn{2}{c}{ Stage , person } & Amount \\
\cline { 2 - 3 } Debil & Male & Famele & \\
Imbesil & 60 & 35 & 95 \\
Idiot & 10 & 20 & 30 \\
& Amount & 76 & 7 & 13 \\
\hline
\end{tabular}

(Source: Result of author joint research with FSB, February 2015)

The condition and behavior of residents with mental retardation at SidoharjoVillage as follows:

1. Physical and mental growth is delayed. They are late how to learning sit, creep, crawl, and walk compared to other children in general. Moreover, they just bea "kembangaben" (bedflower). From childhood to adult age can only sleep, sit, even she/he need others help for just move.

2. Oral communication is not fluent, stammered and unclear. For people who are new to them, it is difficult to understand what is being said and what they want.

3. Brain Memory is limited and tends to be difficult to remember various things ever done.

4. Do not understand how to pay or accept things. Whereas, For mild mental retardation can still be educated, given the skills, and can be asked for help to do certain jobs.

5. While Interrelating with the social environment does not always conform to the prevailing norms. Indeed they lack and /or do not understand the rules that must be maintained in the association of living together. His actions reflect a lack of and/or are unable to distinguish between rights and obligations, consequences of actions, and whether his behavior harms or benefits others.

6. Disrupt/disturb, low attention, hyperactive behavior, confusion, verbal and physical aggression, self-injury, and self-stimulation. Individuals with severe mental retardation symptoms often express extreme maladaptive behavior.

7. Meet the biological/sexual needs. Residents with mild and moderate mental retardation have a sex drive or want to get married like normal citizens in general.

Residents whosemental retardation in the Sidoharjo village have been occurred since the 1970s. This is due to the factors below.

1. Malnutrition

Rice fields and infertile fields and rodent pests have struck the village so that the people live in under poverty line. This condition leads to a decrease in people's purchasing power in meeting their food needs resulting in a lack of nutritious food consumption which has an impact on the decline of nutritional status.

2. Pregnancy care

The heavy terrain and unavailability of affordable health by the citizen, especially for pregnant women. In this village, there was only one village midwife in 1997. Previously when the citizen going to check her 
pregnancy, he must go walk to the District of Badegan a distance of approximately 17 kilometers. Because they do not have money and the road is still muddy it is very rare for the pregnancy to be examined.

3. Water

Soil water levels contain high iron, calcareous, and less iodine, causing the growth of the rear brainis lack.

4. Curse

There are some citizens, especially the older generation who believe that many people suffer mental retardation is the curse of their ancestors because they act to heed the customs in dealing with each other, the environment and with God.

The social behavior of Sidoharjo Village community reflects acceptance behavior. Such social behavior is predisposed by a positive attitude toward mental retardation citizens. Citizens perceive andpity, to see the conditions of the social environment and the suffering experienced by residents with mental retardation. Citizens decide to take the following social actions.

1. Do not hide and not exclude members of his family who are mentally retarded. They also do not forbid their mentally retarded members from going out and hanging out with others. So it is not surprising when visiting this village will often see people with mental retardation go around.

2. Teaching children or family members who have mental retardation to be able to undergo their personal activities such as eating, bathing, washing, peeling, dressing, and others. They do not take the time specifically to teach thembutUsually carried out directly in simultaneously with the implementation of daily activities.

3. Providing food aid, clothing, and boards to residents of mental retardation. Food aid given to residents with mental retardation is not much different from the food they consume in daily, ie corn and cassava. Corn and sweet potatoes were given to residents with mental retardation are often manifested as semi-finished (flour) and ready to consume (rice). Social community in delivering food aid does not always come to the home of retarded mental residents, sometimes they deliver at a time when the mental retardation people go to their house or by theroad near their house then called and giving the aid.

4. Teaching to make household goods and tools to work on the fields such as making traditional food and souvenir such are; tompo, tampah, kukusan, gedhek, encek, garanpacul, garanarit, souvenir, and others. In addition, idiot villagers involve and/or give the employment of mentally retarded citizens in search of goat feed, keep goats, cultivate land and crops and give them wages.

5. Building good spiritual for mental retardation citizens by involving them in spiritual and artistic activities, such as kenduri/ceremonial meal, praying, religious speech, watching movies, entertainment, reyogand others.

6. Involving in various social activities around the environment, such as gathering work, celebration, repairing roads, water channels, and so forth.

7. Establishing an organization to handle or assist the mental retardation community ie Forum SidowayahBangkit (FSB).

As a result of the social community behavior for the residents with mental retardation as follows:

1. They Can socialize with the surrounding environment, even occasionally laughtogether when talking about something that he thinks is funny. People with mental retardation will say hello and answer when asked if the answer is not all of them connect with questions, join jagongan, and gotong-royong.

2. They cook and make goods or household tools such as gedeg, theple, cikrak, encek, and mat although still simple.

3. They Can do minimal household and farm work, such as taking water for cooking, searching and raising livestock, and looking for firewood.

4. They Can perform religious activities such as prayer, recitation, praise, and echoing the call to prayer.

5. They Can behave courteously and in accordance with the norms of society though not all of them. For example ask permission if take not hers, when walking pass near the people who are sitting, he said "nyuwunsewu".

6. They Can carry out biological needs. Residents with mental retardation have biological needs. They often steal attention and tease, some even marry fellow citizens with mental retardation and there is also one of them who sufferer mentalretardation. They can build households and their descendants are normal and some are abnormal.

7. They Can read the signs of nature. Residents of mental retardation while working in the fields when there is a flash of lightning or overcast thickness, they immediately terminate the job. At the time of the rainy season, residents of mental retardation when out of the house carrying plastic as a body wrap (like a raincoat), or wearing a crackle bag as a head protector. Some also wear banana leaves as umbrellas.

8. They Can read, write, and calculate even in a simple level.

9. They Can enjoy and express joy by jogging, be it dangdut, campursari, and reyoganevent. 
10. They Can work on his personal needs such as a take defecatein the river or in thefamily toilet, bath, wash, and dress.

The actor who played an important role in various actions against the above mentally retarded citizens are community leaders, religious leaders, and youth leaders. In addition, they are not just giving counseling and motivating but also real action directly addressing to mental retardation residents. Whereas, The factors that encourage the citizen to help them are:

1. Religious Factor.

Citizens have confidence that the child is a gift of God and the child/citizen of mental retardation is not a disaster.

2. Educational Factors

The majority of idiot villagers are of primary and secondary education. So little by little, they know that mental retardation residents still have potential that can be empowered and not a contagious disease.

3. Cultural Factors

Citizens live their life in the same way and help each other, including helping people with mental retardation. Even residents who do not help or waste mentally retarded citizens are worried about getting social sanctions. This is stipulated in the rules that are mutually agreed upon and serve as guidelines and guidance for citizens in behaving with each other including to the residents of mental retardation.

4. Environmental Factors

The condition of the natural environment is not so promising to encourage citizens to work hard and work hard without ignoring the obligations to god and others who must love each other. Citizens feel themselves in the same boat with the citizens of mental retardation and have a responsibility to help them.

5. Socio-Economic Factors

The Sidoharjovillage as considered based on baseeconomic terms including poor villages. With a rural poverty line of Rp. 240,000 per capita expenditure, households in this village living below the poverty line of 944 households or $56.32 \%$ of the total households of 1,676 households. So people are less concerned about the fate of the citizens of mental retardation. Work for self-sufficiency and his family is already heavy. However, along with the increasingly improving economic conditions, the community is trying to help the residents with mental retardation.

\section{B. Discussion}

Residents with mental retardation in Sidoharjo Village as mentioned above show that they have not only one limitation but more than one disability (dual intellectual disability). They experience physical and mental delays so that they experience various problems in conducting behavioral, family, and social activities. This is not much different from what happened in the village or other places. This condition according to Durand and Barlow (2007: 305-306) is a common condition that occurs in people mental retardation as a result of pathological processes in the brain that cause limitations to intellectual and adaptive function or a weakness that occurs in intellectual function and adaptive function. The mental ability of mental retardation fails to develop fairly. Mentally, intelligence, feelings, and willingness are at a low level, so that the relevant obstacles in the adjustment. AAID (2007) also conveyed that residents of impotent mental retardation and adaptive adjustment.

Factors that may cause many residents have gotten mental retardation in idiot village strengthen the results of previous research. For example, Sunarto (2013) who studied the content of heavy metals and iodine levels in water sources in the region said that groundwater contains iron, lime, iodine and if consumed continuously can damage the growth of the fetus, especially in the brain that is not well developed. The condition was also exacerbated by natural factors, where relatively unfertile soil conditions and rodent pests cause food crises and nutritional needs to be almost unmet. These factors obscure the public perception that mental retardation is a hereditary disease. Not a few facts on the ground that show many residents of mental retardation born of normal parents and parents of mental retardation gave birth to normal children. This is in line with the opinions of Durand and Barlow (2007: 305-306), that the causes of mental retardation are infection or intoxication, metabolic disorders, growth and nutrition, and chromosomal abnormalities.

The result of this social behavior study are in line with Skinner's social behavior theory which states that human behavior takes place in relation to environmental factors that result in or change the environment and cause behavioral changes (Skinner in Ritzer, 1992). This positive attitude according to Thursions (Ahmadi, 2007) that people are said to have a positive attitude towards an object if they like or have a favorable attitude. The attitude of the citizens towards the mental retarders in this village also illustrates the existence of an individual and group consciousness that determines actual or possible actions in social activities. The results of this study are gayut with cognitive dissociation theory that discusses dissociationas a result of conflicting attitudes, thoughts, and behaviors and motivates one to take steps to reduce the discomfort (Leon Festinger and Roger Brown in Azwar, 2011: 46-47). Myers (in Rahman, 2013: 135) explains that the relationship between 
attitudes and behavior may vary because each is an independent factor, but influenced by other very diverse factors such as religion, education, environment, culture and socioeconomic.

The factors behind the social behavior of the people accept the mental retardation of the people above in line with the research have conducted byHendriani et al (2006) where the behavior of the recipient's acceptance of mental retardation is influenced by the existence of a belief that the child is a deposit of God. This is related to the value that Notonagoro (in Nurcahyo and Hanif, 2012: 106) is said to be a conception of moral values, ethical values, and aesthetic values embodied in the norms that guide the attitudes and behavior of human beings. These beliefs according to Azwar 2011: 12) effect on certain behavior and on behavior control.

The social behavior of people towards mental retardation is also facilitated by educational factors. Education is not only a transfer of knowledge and skill but also includes transmission of cultural values and social norms. This education embodies human behavior as a member of society. The social behavior of the people is not only the inheritance of the family but also the product of society as a result of the learning process that produces knowledge and appreciation. The cultural system of rural communities that also affects the social behavior of acceptance. The cultural system organizes and defines human actions and actions. The learning process of this cultural system is done through institutionalization. This is as stated by Soekanto (2006: 155) that the cultural system encompasses the human life supporting the culture and the factors that form the basis of human behavior, both in relation to the physical environment and social environment. Baron and Byrne (2002: 9-13) and Parsons (in Gerungan, 2009: 28) also assert that human social behavior is motivated by social and cultural systems. Parson through Sibenertikatheory says that the social system is a synergy between the various subsystems of social interdependence and interconnectedness. These subsystems are beliefs, goals, norms, status and roles, facilities or facilities, and tension stress. This social system for social functions for adaptation, achievement of expected goals, and integration or togetherness.

The actions of the above mentioned citizens to prove the truth of various studies of cognitive psychology which states that the view of humans as homo economicus is not always rational in determining the choice, sometimes humans can also think irrationally in determining the choice as expressed in behavioral economis and also in constrain theory, where human beings are always overwhelmed by choices that sometimes in the choice of no longer based on the advantages but on the basis of social considerations, emotions, and so forth (Homans in Ritzer, 1992: 196 and Wirawan, 2012: 174-176).

\section{Finding and Proposition}

From the result and discussion of the above research can be presented the findings and research propositions as listed in the table below

Table 3 Findings and Propositions of Social Behavior toward Mental Retardation Residents inKampung Idiot SidoharjoJambonPonorogo

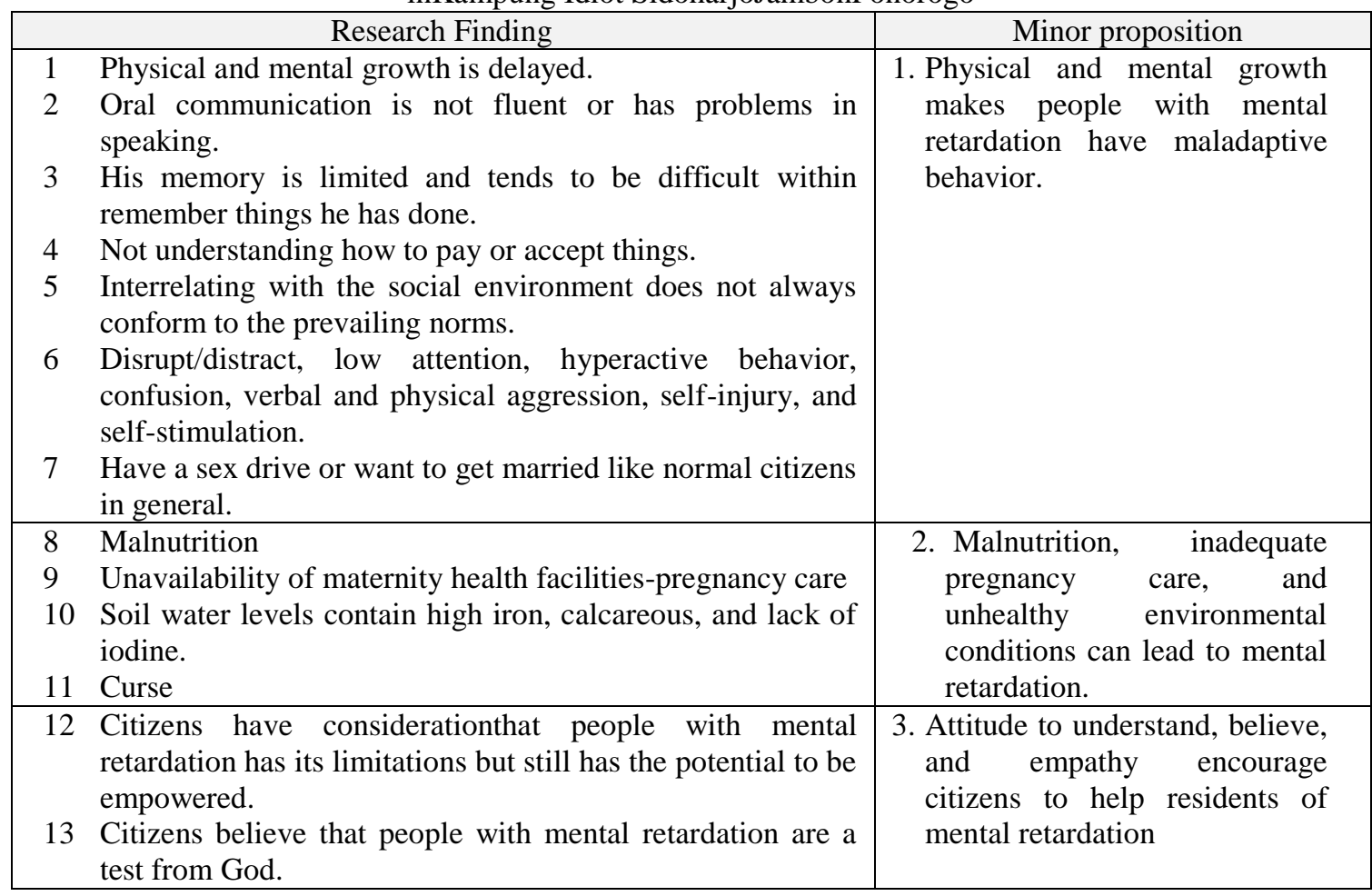


14 Citizens are concerned and help the people of mental retardation in fulfilling their life needs.

15 Citizens hold full consideration toward each people with mental retardation and accept it as part of the community.

16 Residents of the community to familiarize the residents with mental retardation to carry out their personal activities independently.

17 Citizens trained retarded mental citizens to make household goods and utensils and farm goods.

18 Citizens direct the citizens of social retardation socialize and behave in accordance with thenorm.

19 Citizens do not isolate or hide the citizens with mental retardation, even allowing them to mingle and settle down around.

20 Community residents provide food aid, clothing, shelter, and spiritual needs through religious activities and watching art performances.

21 Citizens taught to make household and agricultural goods, keep goats at a simple level and not all programmed.

22 Citizens involve the residents with mental retardation in processing agricultural livestock as well as giving them wages.

23 Citizens ask God for help to overcome the problem of mental retardation by performing traditional ceremonies of tolakbala (village clean ceremony).

24 Residents with mental retardation are able to dress, bathe, urinate and defecate in place.

25 Residents with mental retardation can wash clothes, cook, and clean the house.

26 Residents with mental retardation are able to search for firewood, make household goods, cultivate agricultural land and raise livestock.

27 Residents with mental retardation are able to behave politely, pray and recite.

28 Residents with mental retardation are able to mingle, work together, settle down, enjoy and enjoy art performances.

29 Community leaders, religious leaders, and youth leaders on various occasions provide understanding, encouragement, and example to citizens to help citizens with mental retardation.

30 Community leaders, religious leaders, and youth leaders actively seek help, train, and assist onthe empowerment of mental retardation.

31 The convictionof the child as theentrusted God.hence, the residentswith mental retardation are not a disaster.

32 Knowledge and understanding of mental retardation is not a disease.Therefore, residents withmental retardation still have enviable potential.

33 Help each otherhas become a custom to sustain life through relationships with fellow human beings.

34 A common sense of fate and a strong effort to survive within some environment that does not provide much convenience.

35 Revenue and emotional satisfaction when they can help the residents with mental retardation.
4. The decision to accept, develop self-reliance and encourage socializing is a rational choice of action in dealing with the citizens of mental retardation

5. The act of helping people with mental retardation and giving equal treatment with other citizens, and surrendering to God reflects the socially acceptable citizens

6. Habits, training, and modeling make the residents of mental retardation able to adapt, socialize, and independently.

7. The concerns and actions of community leaders, religious leaders, and youth leaders become role models of citizens

8. Religiosity, adherence to customs, a sense of destiny, the will to sustain life, income and emotional satisfaction mold social behavior of accepting citizens of mental retardation 


\section{Conclusion}

The Residents of Sidoharjo Village have been suffering mental retardations since the 1970s. It is caused by some factors; the lack of nutrient or malnutrition, unavailability of adequate and affordable health facilities for pregnant women, soil moisture content is high, calcareous, and lack of iodine, and "curse". However, The social community behavior towards the citizens with mental retardation reflects the regret and acceptance. Such social behavior had been being disposed by positive attitudes toward the citizens with mental retardation into various beneficial actions; (a) does not isolate or hide the citizens with mental retardation, (b) provide sufficient food, clothing, shelter, and spiritual fulfillment through religious and artistic activities, (c) taughthow to make household and agricultural tools and raise livestock in which is limited and not all programmed, (d) involves in cultivating agricultural land and giving him wages, and (e) involving within customary ceremonies vellage. Therefore, residents with mental retardation residents can live in normal behavioral, family, and social activities, although not maximized.

\section{REFERENCES}

[1] Hanif, Muhammad, Kearifan Lokal Masyarakat dalam Menyikapi Warga Retardasi Mental (Studi Kasus di Kampung Idiot Desa Sidoharjo Kecamatan Jambon Kabupaten Ponorogo), Sodality: Jurnal Sosiologi Pedesaan, 04 (03), December 2016, $242-248$.

[2] Skinner, B.E., Ilmu Pengetahuan dan Perilaku Manusia (Translation of Maufur) (Yogyakarta: Pustaka Pelajar, 2013).

[3] Hurlock,E.,Psikologi Perkembangan suatu Pendekatan Sepanjang Rentang Kehidupan (Jakarta:Erlangga, 1998).

[4] Sarwono, Sarlito W \& Meinarno, Eko A.,Psikologi Sosial (Jakarta: Salemba Humanika, 2011).

[5] Sudrajat,Ahmad, HubunganInterpersonalOrangTua,athttp:/www.Tesis.com.(Accessed on 9February2008).

[6] Ahmadi, Abu, Psikologi Sosial(Jakarta: Rineka Cipta, 2007).

[7] Rahman, Agus Abdul, Psikologi Sosial, Integrasi Pengetahuan Wahyu dan Pengetahuan Empirik (Jakarta: PT RajaGrafindo Persada, 2013).

[8] Baron, Robert A. \& Byrne, D., Psikologi Sosial. Translation of Ratna Djuwita (Jakarta: Erlangga, 2004)

[9] Walgito, Bimo, Psikologi Sosial Sebuah Pengantar (Yogyakarta: CV Andi Offset, 2011).

[10] Ritzer, George, Teori Sosiologi, dari Sosiologi Klasik sampai Perkembangan Terakhir Postmodern (Translation of Saut Pasaribu et. al.) (Yogyakarta: Pustaka Pelajar, 2012).

[11] Wirawan, Ida Bagus,Teori-Teori Sosial Dalam Tiga Paradigma(Jakarta: KencanaPrenada Media Group, 2012).

[12] Azwar, Saifuddin, Sikap Manusia, Teori dan Pengukurannya (Yogyakarta: Pustaka Pelajar, 2011).

[13] Ritzer, Geroge, Sosiologi Ilmu Pengetahuan Berparadigma Ganda (Jakarta: Rajawali Press, 1992).

[14] Myers, David G., Psikologi Sosial (Translation of Aliyani et. al.) (Jakarta: Salemba Humanika, 2012).

[15] Soekanto, Soerjono, SosiologiSuatu Pengantar (Jakarta: PT RajaGrafindo Persada, 2006).

[16] Nevid, J.S., Rathus, S.A,\& Green, B., Psikologi Abnormal (Translation) (Jakarta: Erlangga, 2005).

[17] Durand, Mark V \& Barlow, D.H.,Psikologi Abnormal. Translation of Helly Prajitno Soetjipto \& Sri Mulyantini Soetjipto(Yogyakarta: Pustaka Pelajar, 2007).

[18] Yuliastuti, Pengaruh Latihan rentang Gerak Sendi terhadap Kekuatan Otot Tuna Grahita. Thesis Master of Nursing University of Indonesia, 2011.

[19] Sunarto, Kandungan Logam Berat dan Kadar Sumber Air Kampung Idiot Desa Sidoharjo(Solo: LPPM UNS, research report, 2013).

[20] Nurcahyo, Abraham., Hanif, M.,Ilmu Sosial dan Budaya Dasar(Magetan: LE Swastika, 2012)

[21] Gerungan, WA.,PsikologiSosial(Bandung:Eresco, 2009).

[22] Kartono, Kartini,Psikologi Sosial (Jakarta: Rineka Cipta, 1985). Science (IOSR-JHSS). vol. 22 no. 12, 2017, pp. 41-48. 